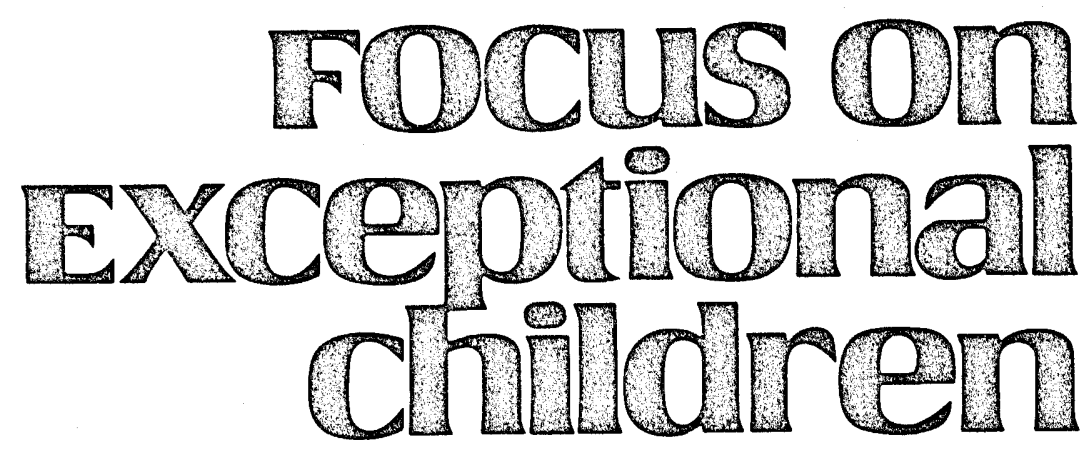

\title{
Variables Related to the Effective Instruction Of Difficult-to-Teach Children
}

\author{
Herbert Rieth and Carolyn Evertson
}

Research on effective instruction for difficult-to-teach students has focused primarily on specific instructional strategies used to teach academic skills. Further, however, research on teaching in regular classrooms and special education programs also has revealed the importance of a number of pre- and post-instructional variables in affecting students' abilities to engage successfully in academic work. Several classes of pre-instructional, instructional, and post-instructional strategies can be employed successfully to increase the task engagement and achievement of difficult-to-teach student (Brophy \& Good, 1986; Rieth \& Frick, 1983; Rieth, Polsgrove, \& Semmel, 1981), as well as student behavior and attitudes (Berliner, 1984).

Pre-instructional strategies, used prior to delivery of instruction, include the elements of advanced preparation and planning. These strategies provide the essential staging area from which effective instruction is launched. They include the arrangement of classroom space and student seating, development of rules and procedures for behavior and academic work, assessment to assist in planning instructional tasks, academic content, communicating learning goals, pacing, and the careful allocation of instructional time. The teacher also can control a series of instructional delivery variables that influence student achievement outcomes and student attitudes. Among them are student engagement time, success rate, academic learning time, and performance monitoring. Finally, certain practices that occur after instruction is delivered (post-instructional strategies) are related to achievement outcomes. They include testing and academic feedback.

All of these variables are important to the education of difficult-to-teach students. They are discussed, with citations for more in-depth reading, in the remainder of this article.

\section{PRE-INSTRUCTIONAL VARIABLES}

Pre-instructional variables involve the following planning considerations.

\section{Planning for Classroom Management}

Classrooms that function well academically throughout the school year are predicated on sound preparation and planning before the year begins (Evertson \& Emmer, 1982b). Teachers who are effective at creating attractive, efficient learning environments make a

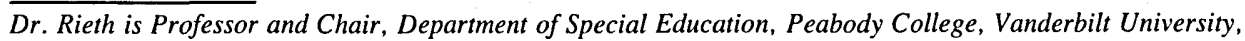
where Dr. Evertson is a Professor of Education in the Department of Teaching and Learning. 
number of organizational decisions, prior to the opening of school, about (a) room arrangement, student desks, and seating, (b) needed rules and procedures, and (c) routines for accomplishing academic tasks and activities (Emmer, Evertson, \& Anderson, 1980).

\section{Arrangement of Classroom Space}

Regardless of how good or bad the available classroom space is, some arrangements of desks, storage areas, bookcases, and displays will facilitate task engagement better than others. Arrangement of physical classroom space signals to students important information about how they are expected to interact with the teacher and with each other, and how they are to accomplish classroom tasks (Rosenfield, Lambert, \& Black, 1985). Effective teachers plan the arrangement of classroom space to accommodate the instructional activities they have planned in order to: facilitate smooth and quick transitions between those activities, maximize their ability to monitor student work and behavior, decrease student noise and disruption, increase the level and quality of student interactions, increase student task engagement, permit students easy access to classroom displays and needed materials, and minimize distractions (Brophy \& Put-

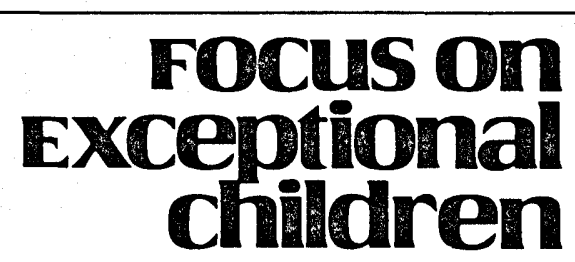

FOCUS ON EXCEPTIONAL CHILDREN (ISSNO015-511X) (USPS 203-360) is published monthly except June, July, and August as a service to teachers, special educators, curriculum specialists, administrators, and those concerned with the special education of exceptional children. This publication is annotated and indexed by the ERIC Clearinghouse on Handicapped and Gifted Children for publication in the monthly Current Index to Journals in Education (CIJE) and the quarterly index, Exceptional Child Education Resources (ECER). It is also available in microform from Xerox University Microfilm, Ann Arbor, MI. Subscription rates: Individuals, $\$ 24$ per year; institutions, $\$ 30$ per year. Copyright (C) 1988, Love Publishing Company. All rights reserved. Reporduction in whole or part without written permission is prohibited. Printed in the United States of America. Second class postage is paid at Denver, Colorado.

POSTMASTER: Send address changes to:

Love Publishing Company

Executive and Editorial Office

1777 South Bellaire Street

Denver, Colorado 80222

Telephone (303) 757-2579

EDITORIAL BOARD

Edward L. Meyen

University of Kansas

Richard J. Whelan

University of Kansas Medical Center
Glenn A. Vergason Glenn A. Vergason
Georgia State University

nley F. Love Publisher
Carolyn Acheson

Senior Editor nam, 1979; Emmer, Evertson, \& Anderson, 1980; Paine, Radicchi, Rossellini, Deutchman, \& Darch, 1983).

Paine et al. (1983) suggest eight organizational space foci that facilitate student task engagement and productivity while reducing off-task, transition time and disruptive behavior:

1. Student desks separated in rows facing the chalkboard and away from windows.

2. Teacher's desk in a front corner of the room facing the students.

3. Classroom partitions to screen off distractions.

4. Teaching stations placed in the corners, enabling the teacher to monitor the behavior of the entire class.

5. A self-correction station facing the wall.

6. A materials station in the front or center of the room.

7. Activity stations for special projects.

8. Bulletin boards for posting scores and displaying materials.

Anderson, Evertson, and Brophy (1979) and Carnine and Silbert (1979) suggest that student task engagement is increased during small-group instruction when students are seated in chairs placed close to the teacher and arranged in a semicircle facing the teacher. They recommend that the teacher sit facing the group in a location that allows the simultaneous monitoring of other students in the class.

\section{Rules and Procedures}

Research has shown that the number of behavioral sanctions teachers use during classroom instructional time is negatively associated with student achievement (Cooley \& Leinhardt, 1980; Brophy, 1979; Rosenshine, 1979). When teachers are forced to focus on disruptive and inappropriate behavior after it has occurred, they do so at the expense of class instructional time. What distinguishes more effective teachers are the measures they take to prevent instances of student misbehavior through carefully planned rules and procedures and well designed academic tasks that engage student interest and attention (Kounin, 1970; Brophy, 1983; Evertson \& Emmer, 1982b).

After rules and procedures are introduced and taught to students, effective teachers systematically follow through on their expectations for good student behavior; they remind students of the rules, monitor for compliance, and reteach or reintroduce procedures and rules when necessary (Brophy \& Evertson, 1976; Emmer et al., 1980; Good, 1983). By careful monitoring, teachers are able to detect inappropriate behavior early and to correct it before it becomes a problem.

With some handicapped students, however, rules may not be enough to reduce or eliminate disruptive and inappropriate behavior (Greenwood, Hops, Delquadri, \& Guild, 1974). Combining rules with social reinforcement for appropriate behavior and ignoring mild transgression increases the likelihood that handicapped students will comply with rules (Madsen, Becker, \& Thomas, 1968; O’Leary, Becker, 
Evans, \& Saudargas, 1969). In cases of severe or persistent behavior problems, the teacher may have to employ punishment procedures in conjunction with reinforcement to reduce student misbehavior (Polsgrove \& Rieth, 1983).

Accommodating up to 30 people in a confined space such as the typical classroom necessarily means planning for physical movement in and out of the room or in and out of small groups. Specific routines promote smooth, quick transitions between activities and, thus, add to instructional time. Routines also reduce disruption that can lead to behavior problems, and they help maintain lesson flow, continuity, and student engagement in academic work. A few necessary classroom procedures might include: designing procedures for smooth passage of students between learning centers, lining up for the water fountain, assigning helpers to collect papers and pass out materials, and putting away work materials prior to leaving for instruction in a resource room.

\section{Managing Student Academic Work}

Much academic work revolves around the completion of assignments. Therefore, teachers' plans should include routines for collecting, checking, and monitoring student academic work (Brophy \& Evertson, 1976; Evertson \& Emmer, 1982a). One way that effective teachers demonstrate purposefulness for learning is by holding students accountable for completion of their work (Good, 1983; Brophy, 1983).

Accountability is the primary force behind task systems; students tend to take seriously only that work for which they are held accountable (Doyle, 1983). Teachers who set up routines that allow students to keep track of assignments (e.g., posting them on the board; students' self-recording scores on daily assignments, keeping a grade sheet with class folders); who monitor student progress and completion rates regularly; and who give regular and specific academic feedback are the most successful in producing student learning gains (Evertson, Emmer, Sanford, \& Clements, 1983; Rieth, Polsgrove, McLeskey, Payne, \& Anderson, 1978).

Paine et al. (1983) suggest that teachers can further reduce the loss of instructional time by having needed instructional materials and assignment completion materials nearby so they are easily accessible. They also suggest that instructional time can be saved by immediately providing students needed materials such as paper and pencils when they get caught without a sharp pencil or run out of their own paper, storing materials and extra supplies near each instructional area, and training students in passing and collecting procedures.

Teachers also might save several minutes a day by marking different group assignments with color-coded clips in the teacher's guide so they can locate the appropriate lesson easily and quickly (Carnine \& Silbert, 1979). Likewise, arranging student materials so the teacher can quickly hand them out will save instructional time and maintain activity flow. These time-saving activities take on added significance when considering that mildly handicapped students typically lose in excess of 45 minutes per day to transition time (Rieth \& Frick, 1983).

Students must be adequately prepared for independent work. Teachers who give clear, explicit, and even redundant instructions, to make sure that all students understand them, are more successful in keeping students engaged in tasks. Anderson (1981), who interviewed elementary students about the purposes of their seatwork, found that many students did not understand the instructional purpose behind their assignments. The students' understanding of its importance was to "finish" and turn it in. In addition, many of the students in this study had difficulty getting started and spent much time in confusion. Lovitt (1977) reported that handicapped children often had difficulty understanding task directions and suggested that teachers model task procedures and problem solution strategies to facilitate prompt task initiation.

Other organizational decisions that effective teachers must make involve planning for the efficient completion of paperwork and other routine nonacademic class business such as taking roll, collecting absentee slips and lunch money, updating IEPs, and instructional record keeping to maximize instructional time (Anderson, Evertson, \& Emmer, 1980; Emmer et al., 1980; Paine et al., 1983). For example, paper correction can be expedited by allowing students to correct their own papers. Farnum and Brigham (1978) reported that elementary school students not only attained a $93 \%$ accuracy rate while grading their own papers, but they also reported that they preferred to correct their own work. Hundert and Bucher (1978) also reported that handicapped students typically were able to score their papers accurately in the absence of teacher monitoring.

\section{Planning Instructional Tasks}

\section{Assessment}

Rieth, Polsgrove, and Semmel (1981) suggest that informal criterion-referenced measures tied to specific objectives and classroom curricula, coupled with continual monitoring of a student's performance in a particular program, not only facilitate accurate placement in an instructional sequence but also provide information that teachers can easily obtain and use for educational decision making. Deno and Mirkin (1978) argue that teachers should collect daily performance measures and compare them to a projected rate of progress established in relation to IEP goals. Curriculum-based progress monitoiring (Deno \& Fuchs, 1987) is a methodology wherein teachers routinely measure student progress toward IEP goals on curriculum-related tasks and, when measurement data indicate student progress toward those goals is inadequate, teachers modify instructional programs in an attempt to improve academic gains. 
The importance of these procedures is supported by a strong and diverse research base demonstrating that curriculum-based progress monitoring enhances the effectiveness of instructing students with handicaps (Rieth, Evertson, $\&$ Fuchs, 1987). Additionally, a recent meta-analysis of the effect of curriculum-based assessment on student achievement (Fuchs \& Fuchs, 1986) found that when handicapped students' academic programs are monitored systematically and developed formatively over time, they gain an average .7 standard deviation units higher than students whose teachers employ the more conventional special education practice of using norm-referenced test data to develop students' programs and then rarely monitoring student progress.

Chow (1981) observed that students with learning disabilities placed in mainstreamed classes spent much less time engaged in academic tasks that offer high success than did regular students in the same class. Conversely, the learning disabled students spent three times more time engaged in academic tasks that offered low success than did regular students in the same class. Mildly handicapped students observed by Rieth and Frick (1983) spent considerably more time than "normal peers" in low task-success activities. In part, these findings suggest that some handicapped students, because of inadequate assessment procedures, are placed in low task-success programs, which serve to perpetuate their placement in resource and self-contained special education programs.

Student assessments also should contain an analysis of the instructional materials and activities that teachers will use to convey the concepts to students. Materials used to support instruction may have embedded problems. Some types of materials can be confusing, tricky, or problematic because they contain, for example, unnumbered items in a spelling list, unclear written directions, ambiguous or unfamiliar terms, or formats separate and apart from the conceptual level of the material (Weade \& Green, 1985).

In addition, teachers should assess the needed concepts or "scaffolding" required for students to understand what the lesson conveys. By developing interactive activities that logically derive from the content, teachers can get feedback on student performance and error patterns, catch misunderstandings, and keep students engaged.

\section{Communication of Learning Goals}

Goals can be defined as the teacher's general aims for learning. Adequate instructional goals are based on careful and appropriate assessment of students' learning needs. They form the basis on which the instructional program can be planned (Clark \& Yinger, 1979). Teachers who are unclear about their learning goals and do not communicate the rationales for academic tasks to students are less effective in promoting student achievement (Tikunoff, Berliner, \& Rist, 1975; Fisher et al., 1980; Berliner, 1982). Both student attention rates and achievement improved when teachers spent more time clarifying goals and giving careful and specific directions.

Lovitt (1977) suggests that teachers can easily learn to give precise instructions regarding goals and learning activities consistently if they will just take a few moments to think them through. In addition, he recommends telling a child that what is expected is an inexpensive, simple way to alter behavior, less nerve wracking and time consuming than many complex and involved remediation routines.

\section{Pacing Decisions}

The organization of content and activities within a time frame may be different for difficult-to-teach students. Evertson (1982) found that sequencing the delivery of lesson content into several presentation-demonstration-practicefeedback cycles, rather than developing plans requiring students to attend to a presentation or to work for 25 to 30 minutes on the same seatwork activity, was more effective with lower ability level classes. With lower ability students, teachers who introduced material in small steps, provided for plenty of practice and used repetitions to the point of overlearning were more effective in producing student achievement gains (Brophy \& Evertson, 1976; Rosenshine, 1983).

Barr (1980) reports that pacing instruction and student work can account for as much as $80 \%$ of the difference in achievement among high and low performers. Effective pacing requires a match between student achievement levels and the difficulty level of the assignment. Difficult-to-teach students require a slower pace, with opportunities for overlearning basic skills. Teachers who aim for relatively high success rates on student assignments before moving on to the next learning activity generally produce more learning than teachers who tolerate greater failure rates (Brophy, 1979).

Numerous studies of elementary and secondary classrooms have identified the effective managment of transitions between activities as essential to maintaining a continuous flow of academic activity (Arlin, 1979; Emmer, Evertson, \& Anderson, 1980; Evertson \& Emmer, 1982a). Quick, smooth transitions not only conserve instructional time, but they also serve to maintain students' focus on learning activities.

\section{Time Allocations}

Time and learning research has consistently demonstrated significant relationships between time spent on learning and student achievement (e.g., Anderson, 1976; Bloom, 1974; Fisher et al., 1980; Stallings, 1980; Walberg, 1982). Paine et al. (1983) suggest three levels of allocated time:

1. The amount of time the students are in school.

2. The amount of time they are in the classroom.

3. The amount of time they are engaged in instruction. 
Wiley (1973) analyzed the amount of allocated instructional time across states; states having longer school years and school days reported greater overall student achievement gains. David (1974) reviewed 20 studies involving allocation time and found a consistent positive relationship between amount of time spent in school and achievement test scores. Paine et al. (1983) reported considerable differences among classrooms serving handicapped students regarding the amount of time allocated for instruction. Reported achievement data suggest that teachers who allocate more time to reading tend to have students with higher achievement test scores in that area.

Rieth and Frick (1983) analyzed the instructional environments provided to mildly handicapped students across service delivery systems. The sample of 25 handicapped students observed in regular, resource, and self-contained special education classes had a school day varying between 5.5 and 6.5 hours in length and averaging 5 hours 50 minutes. During that time students were involved in between 16 and 19 activities per day, and they averaged a little over 45 minutes per day in transition activities. Rieth and Frick also suggest that the amount of instructional time is influenced by effective classroom management skills that not only increase the amount of time spent on instruction but also ensure that the time is continuous and relatively free of distractions, interruptions, and disruptions.

\section{INSTRUCTIONAL DELIVERY VARIABLES}

\section{Engagement Time}

Engagement time refers to the proportion of allocated time in which students are actively engaged in an academic activity. Fisher et al (1978) observed that the correlation between engagement time and pupil achievement is characteristically higher than that between allocation time and achievement, suggesting that students who pay attention and who work more at academic tasks also learn more. Engagement rates reported for elementary school-aged mildly handicapped students served in mainstream, resource, and self-contained special education classes were 75\% (Rieth \& Frick 1983); and Rieth, Bahr, Polsgrove, Okolo, and Eckert (1987) reported that mildly handicapped high school students were engaged approximately $76 \%$. The data from these studies, as well as those reported by Stallings and Kaskowitz (1974) and Soar (1978), indicate much higher engagement in teacher-led than seatwork tasks.

Higher engagement rates have been observed in classes in which the teachers engage in substantive interactions (e.g., explanations, short, factual questions and answers) and provide feedback (Rosenshine, 1979). Hall, Lund, and Jackson (1968) reported increased student engagement during seatwork activities when teachers increased the amount of contingent praise and ignored off-task behavior. These procedures also were found to have "spillover" effects in terms of increasing the task engagement of students seated adjacent to target students (Broden, Bruce, Mitchell, Carter, \& Hall, 1970). Walker and Buckley (1968), among others, successfully used a point system to increase student engagement; and Fisher et al. (1978) reported group studies indicating that teachers who informed students about the accuracy of their performance during instructional activities produced higher student engagement rates and achievement.

Stallings (1980) also acknowledged the relationship of achievement to allocation and engagement time but observed that student learning depends more on how the available time is used. She pointed out that the Follow Through Observation Studies demonstrated that the types of activities in which students were involved were differentially related to achievement in reading and math (Stallings \& Kaskowitz, 1974). Stallings, Stayrook, and Needels (1979), for example, reported that although an average of $4 \%$ of classroom time in remedial secondary classrooms was spent in discussion and review, students in classrooms with more discussion and review made greater academic gains. They also reported that less academic gain occurred in classrooms in which more than an average amount of time was spent on class management, written assignments, and silent reading.

In addition, students with histories of reading problems attained the greatest gains when instruction included support, positive corrective feedback, and higher percentages of oral reading time. Negative correlations were reported between off-task variables and reading gains. These results highlight the necessity for teachers to be able to differentially select effective practices and to effectively manage behavior to facilitate effective use of available time.

Greenwood, Delquadri, and Hall (1984) suggest that students be placed in instructional environments in which they can emit high rates of active rather than passive responses. Active academic responding includes behaviors such as calculating math facts, reading orally, answering questions, playing academic games, pointing to a word, asking questions. Greenwood et al. report that passive responding represents as much as $45 \%$ of instructional time in the school day. Passive responding is viewed as an important academic survival skill, but in the absence of high rates of active responding, it may not be an important factor in the development of academic performance.

Providing students with opportunities to work on essential academic tasks is an important consideration in increasing active task engagement, according to Greenwood et al. (1984). They labeled these activities as opportunities to respond, which were defined as "the interaction between (a) teacher-formulated instructional antecedent stimuli (the materials presented, prompts, questions asked, signals to respond, etc.), and (b) their success in establishing the academic responding desired or implied by the material." Data collected in six inner city classrooms, grades 1 through 
4 , indicated that $75 \%$ of the school day is used for academic instruction. Of that percentage, students responded actively to instruction during only $25 \%$ of the school day. They also reported that student achievement increased as the number of opportunities to respond increased. These data highlight the importance of providing many opportunities to practice academic behavior.

\section{Success Rate}

Fisher et al. (1978) reported a positive correlation between time spent on high-success tasks and student achievement. Their data revealed that pupils who spent more than half of their time on high-success math tasks (tasks on which the students made only occasional errors) produced higher achievement scores, maintained their knowledge longer, and had better attitudes. These results suggest that learning basic skills in the elementary grades requires students to experience success on assigned tasks and to thoroughly master skills.

Rieth and Frick (1983) reported that mildly handicapped elementary school students experienced $43 \%$ high task success, $45 \%$ medium task success, and $12 \%$ low task success. Fisher et al. (1978) reported that a group of second- and fifth-grade regular class students experienced $45 \%$ high task success, $52 \%$ medium task success, and 3\% low task success. The higher low task success experienced by the mildly handicapped students underscores the need for precise, continuous assessment of academic skills and materials to reduce the amount of low task success experienced by handicapped students.

Brophy and Evertson (1976) and Stephens (1976) recommend that students working under direct teacher supervision be given instructional materials and procedures at a level that enables them to respond with between $70 \%$ and $90 \%$ accuracy. When students are working independently, they should receive materials that they can complete with at least $90 \%$ accuracy. Available data indicate that students should experience as much high task success as possible, but there are no data indicating maximum effective percentages of high and medium task success.

\section{Academic Learning Time}

Academic learning time (ALT) is defined as the amount of time students are engaged in academic activities in which they attain high task success rates. ALT encompasses a cluster of instructional and procedural variables that are related to success on student outcome measures. Thus, students who accrue large amounts of ALT appear to benefit substantially. At least, these are the predictions that researchers make for groups of students who experience differential amounts of ALT (Berliner, 1984). The predictions are derived from data collected from 100 elementary school-age students.
Teachers must learn to keep ALT in mind as they instruct, because large differences in the amount of ALT built up by various students generally result in wide variation in student achievement. According to Berliner, teachers must find ways to keep students engaged and see to it that younger or more difficult-to-teach students in particular spend large percentages of their time in high-success experiences. Students and classes that accumulate high levels of ALT are likely to achieve more than students or classes with lower accumulations of ALT.

\section{Monitoring}

Rieth and Frick (1983) reported that student task engagement is higher during seatwork when their performance is monitored. In monitoring, the teacher circulates throughout the class, carefully checking the progress and accuracy of student work, occasionally providing encouragement and specific feedback to students, and providing assistance to students when needed. Rieth and Frick (1983) and Rieth, Bahr, et al. (1987) reported that mildly handicapped students spend about half of their time on seatwork activities. They also reported that the students they studied were 7 times more likely to be off-task when they worked on independent seatwork rather than being assigned teacher-supervised activities. Berliner (1984) and Rieth and Frick (1983) indicate, however, that independent seatwork engagement rates can be increased if the teacher moves rapidly around the classroom, monitoring students' performance and engaging in substantive interactions with them.

The other facet of monitoring is curriculum-based progress monitoring (Deno \& Fuchs, 1987), wherein teachers regularly measure and review student progress toward IEP goals on curriculum-related tasks. This practice is linked to achievement gains for difficult-to-teach students.

\section{POST-INSTRUCTIONAL VARIABLES}

\section{Testing}

Rieth, Polsgrove, and Semmel (1981) suggest that regularly administering informal criterion-referenced measures linked to the classroom curricula subsequent to the delivery of instruction provides teachers with information essential for instructional decision making. The data provide the teacher with immediate student performance information that assists in determining whether to proceed to a more difficult instructional task or to reteach the target task. The systematic use of these measures, in conjunction with routine student performance monitoring, enhances the academic gains of difficult-to-teach students.

\section{Academic Feedback}

A critical component of effective instructional programs for handicapped learners is academic feedback (Gersten, 
Woodward, \& Darch, 1986; Rieth, Bahr, Polsgrove, Okolo, \& Eckert, 1986; Rieth \& Frick, 1983). Rosenshine and Stevens (1984) concluded that low-performing students repeatedly show higher academic achievement when their teachers follow a consistent practice of demonstration, guided practice, and feedback. Rieth, Polsgrove, and Semmel (1981) maintain that immediate knowledge concerning the quality of performance is necessary for the self-correction that characterizes the learning process.

The importance of providing corrective positive feedback has been recurrently documented as an effective procedure for providing instruction (Fisher et al., 1980; Stallings, 1980; Stallings \& Kaskowitz, 1974). Fisher et al. (1980) found that students who had feedback contacts with teachers during seatwork generally had $10 \%$ higher engagement rates than students who did not receive feedback. Collins, Carnine, and Gersten (1987) reported that both basic and elaborative feedback significantly increased students' performance on reasoning skill tasks. They also compared differential effects of two types of feedback and found that both types of feedback successfully increased student performance, but that the elaborated feedback produced the greatest skill acquisition gains. Good and Grouws (1979) reported that teachers moving around and providing feedback to students while they were completing seatwork was considered an illustration of "active teaching," which is related to increased student achievement.

Rieth and Frick (1983) studied the effects of academic feedback on the task engagement of mildly handicapped students. They reported that, in 11 of 14 cases in which teachers increased the amounts of academic feedback, student engagement increased. In two of the three cases in which engagement rates did not increase, the student had baseline engagement rates in excess of $80 \%$ and could not be reasonably expected to increase further. Overall, the major reviews of effective teacher behaviors have all included feedback among the most essential teaching behaviors (Berliner, 1984; Brophy \& Good, 1986; Rosenshine \& Stevens, 1986).

Despite the vast literature documenting the importance of feedback, studies analyzing the behavior of special education teachers and regular teachers found low frequencies of feedback provided to handicapped students. For example, Morsink, Soar, Soar, and Thomas (1986) reported that classroom observations reveal that handicapped students receive little direct instruction and low rates of academic feedback. Thurlow, Ysseldyke, Graden, Greener, and Mecklenburg (1982) reported observing small amounts of feedback provided to learning disabled students. Rieth and Frick (1983), in observing samples of special education and regular classroom teachers who taught mildly handicapped students, found that they provided feedback in less than $10 \%$ of observation intervals. Rieth, Bahr, et al. (1987) studied the behavior of high school resource room teachers and found that they provided feedback during $1 \%$ of the 50 observation intervals.

In summary, studies examining the behavior of teachers responsible for instructing mildly handicapped students report very little academic feedback being provided to students. At the same time, the literature reveals that these students clearly benefit from high amounts of feedback.

\section{SUMMARY}

This article has discussed several classes of pre-instructional, instructional, and post-instructional variables that can successfully increase the task engagement and achievement of difficult-to-teach students. Despite widespread agreement on the positive impact of these variables, data suggest that many of these practices are not being implemented by regular and special education teachers (Morsink et al., 1986; Rieth \& Frick, 1983; Rieth, Polsgrove, Okolo, Bahr, \& Eckert, 1987). For example, Rieth, Polsgrove et al. (1987) observed 52 high school resource room teachers and found that the teachers seemed to use instructional approaches commonly associated with regular high school classrooms-being substantially dependent upon large-group instruction and paperand-pencil materials. Considerable confusion appeared to surround task directions and academic content, and there were relatively low rates of academic feedback. Overall, educational procedures associated with high achievement (e.g., small-group instruction, direct instruction, corrective feedback) were not typically employed by special education teachers in this study.

Thus, there seems to be a gulf between consensus research findings and classroom practice. Clearly, given our knowledge of effective instructional practices, preservice and inservice programs must work with educators to develop strategies that will facilitate implementation of these procedures. Rieth and Frick (1983) have clearly demonstrated that prospective and practicing teachers can be successfully taught to increase their rates of direct instruction to promote high frequencies of active student task engagement. The number of difficult-to-teach students, however, continues to increase. Consequently, there is a continuing need for research to identify and describe additional effective instructional practices and to identify strategies to translate research into strategies that can be readily implemented by classroom teachers who are responsible for educating difficult-to-teach students.

\section{REFERENCES}

Anderson, L.M. (1981). Short-term responses to classroom instruction. Elementary School Journal, $82,97-108$.

Anderson. L.M., Evertson, C.M., \& Brophy, J.E. (1979). An experimental study of effective teaching in first grade reading groups. Elementary School Journal, 79, 193-223.

Anderson, L.M., Evertson, C.M., \& Emmer, E.T. (1980). Dimensions in classroom management derived from recent research. Journal of Curriculum Studies, 12, 343-356.

Anderson, L.W. (1976). An empirical investigation of individual differences in time to learn. Journal of Educational Psychology, 68, 226-233.

Arlin, M. (1979). Teacher transitions can disnupt time flow in classrooms. American Educational Research Journal, 16, 42-56. 
Barr, R. (1980, April). School, class, group, and pace effects on learning. Paper presented at the annual meeting of the American Educational Research Association, New York.

Berliner, D.C. (1982, March). The executive functions of teaching. Paper presented at the annua meeting of the American Educational Research Association, New York.

Berliner, D.C. (1984). The half-full glass: A review of research on teaching. In P.L. Hosford (Ed.), Using what we know about teaching (pp. 51-77). Alexandria, VA: Association for Supervision \& Curriculum Development.

Bloom, B. (1974). Time and learning. American Psychologist, 29, 682-688,

Broden, M., Bruce, C., Mitchell, M.A., Carter, V., \& Hall, R.V. (1970). Effects of teacher attention on attending behavior of two boys at adjacent desks. Journal of Applied Behavior Analysis, 3, 199-203.

Brophy, J.E. (1979). Teacher behavior and its effects. Journal of Educational Psychology, 71, 733-750.

Brophy, J.E. (1983). Classroom organization and management. Elementary School Journal, 83. $265-285$

Brophy, J.E., \& Evertson, C.M. (1976). Learning from teaching: A developmental perspective. Boston: Allyn \& Bacon.

Brophy, J., \& Good, T. (1986). Teacher behavior and student achievement. In M.C. Wittrock (Ed), Handbook of research on teaching. New York: Macmillan.

Brophy, J.E., \& Putnam, J. (1979). Classroom management in the elementary grades. In D. Duke (Ed.), Classroom management: The 78th yearbook of the National Society of the Study of Education (Part 2), Chicago: University of Chicago Press.

Carnine, D., \& Silbert, J. (Eds.) (1979), Direct instruction reading. Columbus, OH: Charles E. Merrill.

Chow, S. (1981). A study of academic learning time of mainstreamed learning disabled students (Final Grant Report \#G007902007). San Francisco: Far West Laboratory for Educational Research \& Development.

Clark, C.M., \& Yinger, R.J. (1979). Three studies of teacher planning (Research Series No. 55). East Lansing: Michigan State University, Institute for Research on Teaching.

Collins, M., Carnine, O., \& Gersten, R. (1987). Elaborated corrective feedback and the acquisition of reasoning skills: A study of computer-assisted instruction. Exceptional Children, 54(3), 254-262.

Cooley, W. W., \& Leinhardt, G. (1980). The instructional dimensions study. Educational Evaluation \& Policy Analysis, 2, 7-25.

David, J.L. (1974). Summer study: A two part investigation of the impact of exposure to schooling on achievement growth. Unpublished doctoral dissertation, Harvard University.

Deno, S.L., \& Fuchs, L.S. (1987, April). Developing curriculum-based measurement systems fo data-based special education problem solving. Focus on Exceptional Children, 19(8), pp. 1-16.

Deno, S.L., \& Mirkin, P.K. (1978). Data-based program modification: A manual. Minneapolis: Leadership Training Institute.

Doyle, W. (1983). Academic work. Review of Educational Research, 53, 159-199.

Emmer, E., Evertson, C., \& Anderson, L. (1980). Effective management at the beginning of the school year. Elementary School Journal, 80, 219-231.

Evertson, C. (1982). Differences in instructional activities in higher-and lower-achieving junior English and math classes. Elementary School Journal, 82, 329-350.

Evertson, C., \& Emmer, E. (1982a). Effective management at the beginning of the school year in junior high classes. Journal of Educational Psychology, 74, 485-498.

Evertson, C., \& Emmer, E. (1982b). Preventive classroom management. In D. Duke (Ed.), Helping teachers manage classrooms. Alexandria, VA: Association for Supervision \& Curriculum Development.

Evertson, C., Emmer, E., Sanford, J., \& Clements, B. (1983). Improving classroom management: An experiment in elementary school classrooms. Elementary School Journal, 84, 173-188.

Farnum, M., \& Brigham, T. (1978). The use and evaluation of study guides with middle school students. Journal of Applied Behavior Analysis, 11, 137-144.

Fisher, C.W., Berliner, D.C., Filby, N.N., Marlaive, R., Cohen, L.S., Deshaw, M.M., \& Moore, J.E. (1978). Teaching and learning in the elementary school: A summary of the Beginnin Teacher Evaluation Study. San Francisco: Far West Laboratory for Educational Research \& Development

Fisher, C.W., Berliner, D.C., Filby, N.N., Marlaive, R., Cohen, L.S., Deshaw, M.M., \& Moore, J.E. (1980). Teaching behaviors, academic learning time, and student achievement: An overview. In C. Denham \& A. Lieberman (Eds.), Time to learn. Washington, DC: National Institute of Education.

Fuchs, L.S., \& Fuchs, D. (1986). Effects of systematic formative evaluation on student achievement. Exceptional Children, 53(2), 199-208.

Gersten, R., Woodward, J., \& Darch, C. (1986). Direct instruction: A research-based approach to curriculum design and teaching. Exceptional Children, 53(1), 17-31.

Good, T.L. (1983). Classroom research: A decade of progress. Paper presented at the annual meeting of the American Educational Research Association, Montreal.

Good, T.L., \& Grouws, D.A. (1979). The Missouri mathematics effectiveness project: An experimental study in fourth-grade classrooms. Journal of Educational Psychology, 71, 355-362.

Greenwood, C.R., Delquadri, J., \& Hall, R.V. (1984). Opportunity to respond and student academic performance. In W. Heward et al. (Eds.), Focus on behavior analysis in education. Columbus, $\mathrm{OH}$ : Charles E. Merrill.

Greenwood, C.R., Hops, H., Delquadri, J., \& Guild, J. (1974). Group contingencies for group consequences in classroom management: A further analysis. Journal of Applied Behavior Analysis, 7, 413-425.

Hall, R.V., Lund, D., \& Jackson, D. (1968). Effects of teacher attention on study behavior. Journat of Applied Behavior Analysis, I, 1-12.

Hundert, J., \& Bucher, B. (1978). Pupils' self-scored arithmetic performance: A practical procedure for maintaining accuracy. Journal of Applied Behavior Analysis, $I I, 304$.

Kounin, J. (1970). Discipline and group management in classrooms. New York: Holt, Rinehart \& Winston.

Lovitt, T.C. (Ed.). (1977). In spite of my resistance, I've learned from children. Columbus, $\mathrm{OH}$ : Charles E. Merrill.
Madsen, C.H., Becker, W.C., \& Thomas, D.R. (1968). Rules, praise, and ignoring: Elements of elementary classroom control. Journal of Applied Behavior Analysis, I, 139-150.

Morsink, C.V., Soar, R.S., Soar, R.M., \& Thomas, R. (1986). Research on teaching: Opening the door to special education classrooms. Exceptional Children, 53(1), 32-40.

O'Leary, K., Becker, W., Evans, M., \& Saudargas, R.A. (1969). A token reinforcement program in a public school: A replication and systematic analysis. Journal of Applied Behavior Analysis, $2,3 \cdot 13$

Paine, S.C., Radicchi, J., Rossellini, L.C., Deutchman, L., \& Darch, C. B. (Eds.). (1983). Structuring your classrooms for academic success. Champaign, IL: Research Press.

Polsgrove, L., \& Rieth, H.J. (1983). Procedures for reducing children's inappropriate behavior in special education settings. Exceptional Education Quarterly, 3, 20-33.

Rieth, H.J., Bahr, C., Polsgrove, L., Okolo, C., \& Eckert, R. (1986). The effects of microcomputer on the secondary special education classroom ecology (Technical Report \#202). Nashville, TN: Vanderbilt University.

Rieth, H.J., Bahr, C., Polsgrove, L., Okolo, C., \& Eckert, R. (1987). The effects of microcomputers on the secondary special education classroom ecology. Journal of Special Education Technol ogy, $8(4), 36-43$.

Rieth, H.J., Evertson, C., \& Fuchs, L. (1987). An analysis of variables that influence the translation and implementation of research results (U.S. Office of Education grant). Nashville: Vanderbilt University.

Rieth, H.J., \& Frick, T. (1983). An analysis of the impact of instructional time with different service delivery systems on the achievement of mildly handicapped students (Final Grant Research Report). Bloomington: Indiana University, Center for Innovation in Teaching the Handicapped.

Rieth, H.J., Polsgrove, L., McLeskey, J., Payne, K., \& Anderson, R. (1978). The use of self-recording to increase the arithmetic performance of severely behaviorally disordered students. Monographs in Behavioral Disorders, 2, 50-58.

Rieth, H.J., Polsgrove, L., Okolo, C.. Bahr, C., \& Eckert, R. (1987). An analysis of the secondary special education classroom ecology with implications for teacher training. Teacher Education \& Special Education, /(3), 113-119.

Rieth, H.J., Polsgrove, L.. \& Semmel, M.I. (1981). Instructional variables that make a difference: Attention to task and beyond. Exceptional Education Quarterly, 2, 61-82.

Rosenfield, P., Lambert, N., \& Black, A. (1985). Desk arrangement effects on pupil classroom behavior. Journal of Educational Psychology, 77, 101-108.

Rosenshine, B. (1979). Content, time, and direct instruction. In P. Peterson \& H. Walberg (Eds.), Research on teaching: Concepts, findings, and implications. Berkeley, CA: McCutchan.

Rosenshine, B. (1980). How time is spent in elementary classrooms. In D.C. Denham \& A Lieberman (Eds.). Time to learn. Washington. DC: National Institute of Education.

Rosenshine, B. (1983). Teaching functions in instructional programs. Elementary School Journal, 83(4), 335-35!.

Rosenshine, B., \& Stevens, R. (1984). Classroom instruction in reading. In R.D. Pearson (Ed.) Handbook of research on teaching. New York: Longman.

Rosenshine, B., \& Stevens, R. (1986). Teaching functions. In M.C. Wittrock (Ed.), Handbook of research on teaching (pp. 376-391). New York: Macmillan.

Soar, R. (1978). Setting variables, classroom interaction multiple pupil outcomes. Paper presented at the annual meeting of the American Educational Research Association Meeting, Toronto.

Stallings, J.A. (1980). Allocated academic learning time revisited, or beyond time on task. Educa tional Researcher, 9, 11-16

Stallings, J., \& Kaskowitz, D. (1974, August). Follow Through classroom observation evaluation 1972.1973. Stanford, CA: Stanford Research Institute. (SRI Project URU.7370.).

Stallings, J., Stayrook, N., \& Needels, M. (1979). The teaching of basic reading skills in secondary schools, Phase II and Phase III. Menlo Park, CA: SRI International.

Stephens, T.M. (1976). Directive teaching of children with learning and behavioral handicaps. Columbus, $\mathrm{OH}$ : Charles E. Merrill.

Thurlow, M.L., Ysseldyke, J.E., Graden, J., Greener, J.W., \& Mecklenberg, C. (1982). Academic responding time for $L D$ students receiving different levels of special education services (Report 78). Minneapolis: Institute for Research on Learning Disabilities.

Tikunoff, W., Berliner, D., \& Rist, R. (1975). An ethnographic study of forty classrooms of the Beginning Teacher Evaluation Study know sample (Technical Rep. 75-10-5). San Francisco: Far West Laboratory for Educational Research \& Development.

Walberg, H.J. (1982). What makes schooling effective? An analysis and critique of three national studies. Contemporary Education Review, $11,102-120$

Walker, H.M., \& Buckley, N. (1968). The use of positive reinforcement in conditioning attending behavior. Journal of Applied Behavior Analysis, 1, 245-252.

Weade, R., \& Green, J. (1985). Talking to learn: Social and academic requirements for classroom participation. Peabody Journal of Education, 62, 6-19.

Wiley, D.E. (1973, July). Another hour, another day: Quantity of schooling, a potent pat for policy (Studies of Educative Processes, No. 3). Chicago: University of Chicago.

This document was produced with support from Grant G00730208 from the United States Department of Education. The contents do not, however, reflect the policy or views of the Department of Education and no official endorsement should be inferred. 